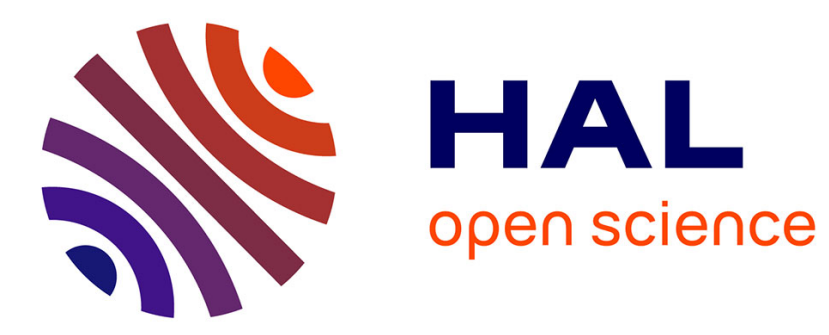

\title{
The Informational Contribution of Social and Environmental Disclosures for Investors
}

Denis Cormier, Marie-Josée Ledoux, Michel Magnan

\section{To cite this version:}

Denis Cormier, Marie-Josée Ledoux, Michel Magnan. The Informational Contribution of Social and Environmental Disclosures for Investors. Crises et nouvelles problématiques de la Valeur, May 2010, Nice, France. pp.CD-ROM. hal-00481571

\section{HAL Id: hal-00481571 \\ https://hal.science/hal-00481571}

Submitted on 6 May 2010

HAL is a multi-disciplinary open access archive for the deposit and dissemination of scientific research documents, whether they are published or not. The documents may come from teaching and research institutions in France or abroad, or from public or private research centers.
L'archive ouverte pluridisciplinaire HAL, est destinée au dépôt et à la diffusion de documents scientifiques de niveau recherche, publiés ou non, émanant des établissements d'enseignement et de recherche français ou étrangers, des laboratoires publics ou privés. 
The Informational Contribution of Social and Environmental Disclosures for Investors

\author{
Denis Cormier \\ Marie-Josée Ledoux \\ École des sciences de gestion \\ Université du Québec à Montréal \\ CP 8888, succ. Centre-ville \\ Montréal, Québec H3C 3P8 \\ Michel Magnan \\ École de gestion John-Molson \\ Université Concordia \\ 1455 de Maisonneuve West \\ Montréal, Québec H3G 1M8
}

The authors acknowledge the financial support of the Social Sciences and Humanities Research Council of Canada, Fonds FQRSC, the Lawrence Bloomberg Chair (Concordia) and the Financial Information and Organizational Reporting Chair (UQAM). 


\section{The Informational Contribution of Social and Environmental Disclosures for Investors}

Corporations increasingly define their social and environmental initiatives and activities as part of their Corporate Social Responsibility (CSR). Disclosure practices have followed suit as well with social and environmental information typically being combined, often through a CSR report. The emergence of CSR

is a response to the demands of activist investors, ethical and green institutional investors as well as rating services (e.g., Jantzi) which evaluate corporations through the lens of CSR, thus going beyond traditional environmental indicators. However, is this trend beneficial to investors? We investigate whether social disclosure and environmental disclosure substitute or complement each other in reducing information asymmetry between managers and investors, taking into account a firm's environmental performance and governance attributes. Our findings suggest that social disclosure and environmental disclosure substitute each other in reducing stock market asymmetry, as proxied by share price volatility. Our results also show that the reduction in share price volatility is higher for economic (hard) environmental disclosure than for generic (soft) environmental disclosure. Hence, future research in CSR disclosure may fruitfully distinguish between social and environmental disclosures as well as between hard (economic-based) and soft environmental information.

Key words: Environmental disclosure, governance attributes, information asymmetry, social disclosure. 


\section{The Informational Contribution of Social and Environmental Disclosures for Investors}

\section{Introduction}

Many investors and other financial market participants are increasingly being attracted to Socially Responsible Investing (SRI, otherwise known as ethical or sustainable investing) (Renneboog, Horst and Zhang, 2008). For instance, the Social Investment Forum (2010) reports that more than $10 \%$ of assets under management in the United States (close to $\$ 3$ trillion out of \$25 trillion) are now invested under SRI criteria. In light of investors' needs for guidance and reliable benchmarks to orient their investment strategy, several indices have emerged such as the Jantzi Social Index (Canada), Dow Jones World and Dow Jones STOXX Sustainability Indexes (United States, Europe, international). The construction of these indices relies on Corporate Social Responsibility (CSR) indicators from various information sources, either external or internal (Ziegler and Schroder, 2009). Among these sources, a firm`s CSR own internal disclosure: for example, the Dow Jones Sustainability Indices reflect both environmental and social reporting.

However, most voluntary disclosure guidelines (e.g., Global Reporting Initiative or GRI) as well as most prior research view corporate social responsibility (CSR) disclosure as an additive process where more is better (e.g., Ingram, 1978; Patten, 1991). In other words, it is assumed that more social and environmental disclosure benefits the disclosing firm as well as its shareholders. There is anecdotal and empirical evidence that, on their own, both social disclosure (e.g. Downing, 1997; Cormier, Ledoux and Magnan, 2009; Cormier, Aerts, Ledoux and Magnan, 2009) and environmental disclosure (e.g. Cormier, Magnan and Morard, 1993; Barth and McNichols, 1994; Li and McConomy, 1999; Aerts, Cormier and Magnan, 2008) convey value- 
relevant information to investors. However, such evidence is not conducive to the development of efficient disclosure practices since it is likely that there is much overlap in the strategies underlying a firm's social and environmental actions and performance. Moreover, despite the growth and development of CSR disclosure by many organisations, it is still relatively unknown as to how investors interpret social and environmental disclosures together. Moreover, it is still uncertain as to how investors integrate a firm`s CSR performance into their assessment of CSR disclosure.

In this study, we investigate whether social disclosure and environmental disclosure substitute or complement each other in reducing information asymmetry between managers and investors, taking into account a firm's environmental performance and governance attributes. Our study focuses on a sample of large Canadian firms. Share price volatility is the measure of information asymmetry. Our study builds upon the intuition of Neu, Warsame and Pedwell (1998) who offer a tentative template to analyze CSR by treating social disclosure as a determinant of environmental disclosure. They argue that social disclosure helps investors to frame the interpretation of environmental disclosures.

Our results suggest that social disclosure and environmental disclosure substitute each other in reducing stock market asymmetry. This result suggests that future research in CSR disclosure may fruitfully distinguish between social and environmental disclosure. Our findings also show that the reduction in share price volatility is higher for hard environmental disclosure than for soft environmental disclosure. As expected, we observe that objective measures of environmental performance are negatively associated with environmental and social disclosure. Our results also show that environmental news exposure and firm size are key drivers of CSR disclosure. 
We contribute to the literature on the determinants of information asymmetry between managers and investors. First, we show that voluntary social-related CSR disclosure reinforces the information value of environmental disclosure, even substituting or compensating for it under certain conditions. In that sense, we extend prior findings that social disclosure (e.g. Cormier, Ledoux and Magnan, 2009) and environmental disclosures (e.g. Barth and McNichols, 1994; Aerts, Cormier and Magnan, 2008) do influence capital market participants.

We also document that a firm's governance influences the extent of its CSR disclosure and, ultimately, affects information asymmetry between managers and investors. These findings are consistent with those reported by Bushman, Chen, Engel and Smith (2003) for the determination of financial reporting. In this sense, by showing that CSR disclosure is an extension of a firm`s governance, our findings are consistent with Jackson and Apostolakou's (2009) argument that voluntary CSR practices substitute for stakeholder participation while preserving owners' influence.

Our study also provides some insights for managers wishing to enhance the efficiency of the message that they convey to investors and other stakeholders. Currently, there is much emphasis on just increasing the number of disclosed information items, without much consideration as to their incremental or substitute effect on investors' decision-making. For example, the GRI reporting framework is gaining recognition around the world but its scope is continuously being revised and augmented. However, such disclosures are not cost-free for organizations. Furthermore, investors must gauge, assess and retain an increasing flow of information: a more efficient disclosure strategy becomes critical if firms want investors to get the right picture of their CSR performance. In that regard, to the best of our knowledge, our study is the first to investigate the joint effect of social and environmental disclosure on 
information asymmetry between managers and investors, taking into account environmental performance and governance attributes. Moreover, our findings are consistent with Lenzen, Dey and Murray's (2004) call for more careful measurement of CSR reporting.

The remainder of the paper is organized as follows. Section 2 contains a theoretical background. The study's methodology is described in section 3. Results are presented in section 4. Finally, section 5 provides a discussion of the potential implication of the results.

\section{Environmental and Social Disclosures: Background and Hypotheses}

\subsection{Corporate Social Responsibility}

Corporate Social Responsibility (CSR) can be broadly understood as the way firms integrate social, environmental and economic concerns into their values, culture, decision making, strategy and operations. CSR is an evolving concept and its underlying construct has changed over time (Carroll, 1999). Such integration must be accomplished in a transparent and accountable manner, thereby leading to the implementation of better practices within the firm, creating wealth and improving society (Industry Canada, 2006). The World Business Council for Sustainable Development describes CSR as the business contribution to sustainable economic development. Beyond complying with legislation and regulations, CSR typically includes commitments and actions related to (not an all-inclusive list):

- corporate governance and ethics;

- $\quad$ health and safety;

- environmental stewardship;

- human rights (including core labour rights); 
- human resource management;

- community involvement, development and investment;

- involvement of and respect for Aboriginal peoples;

- corporate philanthropy and employee volunteering;

- anti-bribery and anti-corruption measures;

- accountability, transparency and performance reporting;

- $\quad$ supplier relations, for both domestic and international supply chains.

These elements of CSR are frequently interconnected and interdependent, and apply to firms wherever they operate. CSR has recently emerged as a critical concern for management. Integrating its actions within a clear CSR strategy helps organizations position themselves to proactively manage risks and take advantage of opportunities, especially with respect to their corporate reputation and broad engagement of stakeholders. The latter can include shareholders, employees, customers, communities, suppliers, governments, non-governmental organizations, international organizations and other organizations affected by a company's activities.

\subsection{Corporate Social Responsibility and Capital Markets}

Ultimately, CSR is about performance, i.e., moving beyond words on a page to effective and observable actions and societal impacts. In that regard, there is extensive evidence that CSR efforts often translate into improvements in a firm's financial performance (see, among others, McWilliams et al., 2006; Margolis and Walsh, 2003; Roman et al., 1999; Griffin and Mahon, 
1997; Pava and Krausz, 1995; Wood and Jones, 1995; Orlitzky et al., 2003; Richardson and Welker, 2001; Cormier, Ledoux and Magnan, 2009).

However, the impact of a firm's CSR actions or initiatives can be analyzed more precisely by dividing them into two broad categories: social-related and environmental-related actions and initiatives. Social-related CSR emerges from relationships between an organisation and its employees, business partners and other stakeholders, and provides opportunities to create value (Burt, 1992). In that regard, Adler and Kwon (2002) note that social-related CSR facilitates various important organizational actions such as inter-unit and inter-firm learning, thus contributing to their success. Moreover, by building up its social dimension, a firm is able to effectively reduce its market-based risk profile (Orlitzky and Benjamin, 2001). For example, Waddock and Graves (1997) suggest that stable relations with various stakeholder groups facilitate a firm's access to equity markets. Improvements in the social facets of CSR also build trust in contracting relationships with external stakeholders, thus enabling the firm to lower transaction costs (Hill, 1990) and subsequent monitoring and coordination costs (Milgrom and Roberts, 1992). Hitt, Lee and Yucel (2002) show that multinational firms engaging in socialrelated activities acquire a competitive advantage in the new global marketplace.

Over the past few years, the environmental dimension of CSR has become quite important and more visible. The emergence of various stock market indices (e.g., Dow Jones Sustainability Index) listing firms that are perceived to be "green" and the creation of sustainable development investment funds are two illustrations of that trend. Environment-related CSR reflects how a firm, through its actions or initiatives, is becoming "green", i.e., with minimal ecological impacts (e.g., Feier and Haskell, 2008). Overall, prior research suggests that the value 
implications from adopting a greening strategy are generally positive, albeit with some contextspecific conditions or aspects (see, among others, Ambec and Lanoie, 2008).

\subsection{Corporate Social Responsibility Disclosure}

In an attempt to be transparent and accountable toward their stakeholders, many organizations now issue CSR reports or disclose extensive information about CSR issues in their annual report or in a complementary report. The Global Reporting Initiative (GRI) provides a broad-based framework for the development of CSR disclosure strategies, with guidance on report content, the type of indicators to be selected or the CSR facets (environmental, human rights, etc.) to be discussed (http://www.globalreporting.org/ReportingFramework). There is extensive literature that reviews and synthesizes CSR reporting by organizations, most specifically its characteristics as well as determinants (e.g., Gelb and Strawser, 2001).

However, the relevance and credibility of a firm's overall CSR disclosure can still be questioned. For example, there is considerable potential for problems when stakeholders perceive that a firm is just engaging in a public relations exercise and cannot demonstrate concrete action that leads to real social and environmental benefits. In that regard, Gray and Bebbington (2007) highlight that a relatively small proportion of firms that are listed worldwide provide CSR disclosure. Moreover, they argue that, even among those firms showcasing their CSR activities, the average quality of disclosure is so uneven as to be useless for meaningful analyses and comparisons.

In addition, the impact of a firm's social disclosure on information asymmetry between managers and investors can only be effective if the firm's social capital traits are visible and 
salient in the market, for example through social performance reputation ratings (Fombrun and Shanley, 1990). In this vein, a corporate disclosure policy is important in supporting the lasting effects of its social capital on market-based risk and performance measures. In that regard, Cormier, Ledoux and Magnan (2009) show that social disclosure reduces a firm's cost of equity capital. With respect to environmental disclosure, Aerts, Cormier and Magnan (2008) find that it is associated with a decrease in analysts' forecast dispersion both in continental Europe and in North America.

Moreover, it is likely that the mapping between CSR disclosure and its appreciation by capital market participants is more subtle than just assuming that more is better. Findings from two studies provide tentative frameworks to consider the issue. On the one hand, Neu, Warsame and Pedwell (1998) treat social disclosure as a determinant of environmental disclosure. The authors argue that social disclosure enhances environmental disclosure credibility by constructing the image of socially responsible organizations harmonizing with environmental disclosure. On the other hand, Godfrey et al. (2008) find that a firm's participation in institutional CSR activities (i.e., that benefit society at large) provide an insurance-like benefit when it faces legal/regulatory actions. In other words, these CSR activities help build up capital for the firm and minimize negative market implications, thereby reducing information asymmetry for investors for these specific firms. Both findings suggest that CSR disclosure may affect the level of information asymmetry between a firm and investors through an interaction between social-related CSR disclosure and environmental-related CSR disclosure. This view contrasts with the current practice of considering both as complementary.

\section{$2.4 \quad$ Hypotheses}


There is anecdotal and empirical evidence that both social disclosure (e.g. Downing, 1997; Cormier, Ledoux and Magnan, 2009; Cormier, Aerts, Ledoux and Magnan, 2009; Richardson and Welker, 2001) and environmental disclosure (e.g. Cormier, Magnan and Morard, 1993; Barth and McNichols, 1994; Li and McConomy, 1999; Aerts, Cormier and Magnan, 2008) affect investors' appreciation of a firm's underlying risk. For example, Cormier, Ledoux and Magnan (2009) show that web-based social disclosure is associated with a larger earnings multiple, i.e. a lower cost of capital. However, in the absence of empirical evidence to the effect that social and environmental disclosures substitute or complement each other in reducing information asymmetry between managers and investors, our research attempts to test the following alternative hypotheses:

H1a: There is a substitution effect between social and environmental disclosures in reducing information asymmetry.

H1b: There is a complementary effect between social and environmental disclosures in reducing information asymmetry.

Cho and Patten (2007) argue that the legitimizing nature of different types of environmental disclosures is not identical and that it is important to distinguish between different types of information when assessing legitimization effects. They primarily distinguish between litigation related and non-litigation related disclosure. This dichotomous split of disclosure types resembles the distinction made by Clarkson, Li, Richardson and Vasvari (2008) between soft and hard environmental disclosures, with hard disclosures reflecting factual, objective information 
that cannot easily be mimicked by poor environmental performers. Finally, Aerts and Cormier (2009) show that soft environmental disclosure is more incentive-consistent than hard

(economic-based) disclosure. Economic-based types of information focus on the financial, legal and operational consequences of corporate environmental activities.

We anticipate the relation between environmental disclosure and share price volatility to be higher for hard disclosure than for soft disclosure. Hence, the following hypothesis, which holds irrespective if the relation between social and environmental CSR disclosures are substitute or complementary:

H2: The reduction in information asymmetry is higher for hard environmental disclosure than for soft environmental disclosure.

\section{Method}

\subsection{Sample}

The sample comprises 137 observations of web disclosure for the year 2005. We initially collected web disclosure in the summer of 2002 for an international study (XXX, 2007). All nonfinancial firms represented on the Toronto Stock Exchange S\&P/TSX Index were identified (the total index comprises 220 firms in the summer of 2002). The resulting 2002 sample comprised 189 non-financial firms. Mergers and acquisitions, bankruptcies and delistings reduced our sample to 157 in 2005 . The final sample comprises 137 firms since, out of the initial sample of 157 firms, there are missing data for board size and board independence, and share volatility. Sample firms represent more than $80 \%$ of the Toronto Stock Exchange capitalization for nonfinancial firms and $46 \%$ of total capitalization. Sample firms operate in the following industries: 
Metals and mines; Gold and precious metals; Oil and gas; Paper and forest products; Consumer products; Industrial products; Real estate; Utilities; Communication and media; Merchandising. Financial data was collected from the Stock Guide and data about governance attributes was collected from 2004 proxy statements, those available in the spring of 2005.

\subsection{Empirical Model}

This study attempts to provide an integrated analysis of a firm's social and environmental disclosure strategy. We posit that this strategy simultaneously affects information asymmetry and disclosure. Based on prior literature, we use share price volatility as a proxy for information asymmetry. The following simultaneous equations model summarizes the approach adopted in the empirical analysis (we will use share price in place of share price volatility as a sensitivity analysis):

\section{Dependent variable}

Share price volatility it $=$

$f\left(b_{0}+b_{1}\right.$ Systematic risk $+b_{2}$ Free float $+b_{3}$ Analyst following $+b_{4}$ Environmental disclosure $+b_{5}$ Environmental disclosure $*$ Social disclosure median $+b_{6}$ Social disclosure $+b_{7}$ Social disclosure* Environmental disclosure median) ${ }_{\text {it }}$

Instrumented variable: Environmental disclosure, Social disclosure

Instruments: Environmental performance, Free float, Analyst following, Leverage, Profitability, Firm Size, Board independence, Board size, Board size squared, Audit committee size, Environmental news exposure. 
Several approaches to assess a firm's information asymmetry coexist. Francis, Khurana and Pereira (2005), Leuz and Verrecchia (2000), Healy Hutton and Palepu (1999) and Welker (1995) show that the extent of information asymmetry - proxied by bid-ask spread, share price volatility or stock liquidity (trading volume) - is negatively associated with disclosure. In the current study, we will use share price volatility and trading volume to assess the relation between information asymmetry and social and environmental disclosures.

Environmental disclosure is measured using a coding instrument in a manner similar to Wiseman (1982), Cormier and Magnan (2003), Al-Tuwaijri, Christensen and Hughes (2004) and Aerts and Cormier (2009). The grid comprises 39 items measuring environmental disclosure quality where the items are grouped into six categories as follows:

Expenditures and risk;

Laws and regulations;

Pollution abatement;

Sustainable development;

Land remediation; and

Environmental management.

The rating is based on a score from one to three. Three points are awarded for an item described in monetary or quantitative terms, two are awarded when an item is described specifically, and one is awarded for an item discussed in general. The information is coded according to the grid presented in appendix 1 .

We believe that the use of a coding scale to qualify a firm's environmental disclosure is appropriate for the following reasons. First, it allows for some integration of different types of 
information into a single figure that is comparable among firms in terms of relevance. Second, while other disclosure studies rely on word counts to measure environmental disclosure (e.g., Neu, Warsame and Pedwell, 1998; Williams and Ho Wern Pei, 1999), a qualitative scale allows the researcher's judgment to be utilized in rating the value or quality of the disclosures made by a firm. While this process is more subjective, it ensures that irrelevant or redundant generalities are not considered strategic environmental disclosures.

We collected social and environmental disclosure from firms' web pages including annual reports, environmental/sustainability reports and information directly presented on web sites in HTML format. We then eliminated any overlap between these three communication media. The grid comprises 16 items measuring social disclosure where the items are grouped into three categories as follows: Labour practices and decent work, Society, Consumer and product responsibility.

Social capital refers to features of social organization, such as networks, norms and social trust that facilitate co-operation for mutual advantage (Industry Canada, 2008). Social disclosure items relate to interactions between the firm and society (e.g., alliances, clients) and within the firm itself (e.g. Dess and Shaw, 2001; Pastoriza, Arino and Ricart, 2008). Social indicators are based on balance scorecard literature and performance measurement practices (e.g. Pirchegger and Wagenhofer, 1999; Marston and Polei, 2004). We measure social disclosure using a coding instrument that is consistent with Wiseman (1982), Cormier and Magnan (2003), Aerts, Cormier and Magnan (2007) and Cormier, Ledoux and Magnan (2009). Like the environmental disclosure grid, three points are awarded for an item described in monetary or quantitative terms, two are awarded when an item is described specifically, and one is awarded for an item discussed in general (see appendix 1). 
To ensure consistency across firms, two persons reviewed all individual scores independently. All disagreements were subsequently reviewed by one of the co-researchers. ${ }^{1}$

Concerning the environmental news exposure, we searched for articles related to environmental issues contained in the $\mathrm{ABI} /$ Inform Global database using the keywords mentioned above. A total of 59 relevant stories were identified for 2004 (See appendix 2 for details).

For the data regarding governance attributes, we rely on 2004 proxy statements since we collected governance disclosure web sites during the spring of 2005 , i.e. in line with information available from the more recent proxy statement available at that time, namely 2004 . Share price volatility is defined as the standard deviation of percentage changes in daily stock prices for 2005.

\subsubsection{Determinants of Share Price Volatility}

Prior studies on the determinants of information asymmetry between managers and investors suggest numerous determinants other than voluntary disclosure (Leuz and Verrecchia, 2000). Based on that literature, we use systematic risk, free float and analyst following as determinants of share price volatility.

1 A coding manual documenting coding instructions as well as standardized coding worksheets were prepared beforehand. Each coder then applied the following coding sequence: (1) independent identification of the occurrence of items relative to the different coding categories; (2) independent coding of the items according to quality level of content and (3) timed reconciliation on a subset of company reports. The coders were intensively trained in applying coding instructions and in using the coding worksheets. They were unaware of the research hypotheses. Initial differences in identifying grid items accounted for, on average, $7 \%$ of the maximum number of items identified. Of the information quality level coding, less than $10 \%$ had to be discussed for reconciliation. Disagreement between coders mostly occurred at the beginning of the coding process (essentially the first 5 firms by industry). A researcher reconciled coding disagreements exceeding $5 \%$ of the highest total score between the two coders. Smaller disagreements were resolved by the two coders themselves. Overall, we think that this coding process provides a reliable measure of environmental reporting. Internal consistency estimates (Cronbach's alpha on score components) show that the variance is quite systematic (from alpha 0.72 for environmental disclosure-Press releases to 0.82 for paper-based environmental disclosure). 
Systematic risk. The higher a firm's systematic risk, the more difficult it is for investors to precisely assess a firm's value and the more likely they are expected to incur information costs to assess its risk drivers. Prior research shows that investors charge a higher cost of equity for firms with higher systematic risk (e.g. Leuz and Verrecchia, 2000; Hail and Leuz, 2006; Botosan and Plumlee, 2005; Mikhail, Walther and Willis, 2004; Gebhardt, Lee and Swaminathan, 2001; and Botosan, 1997). A positive relation is expected between systematic risk and share price volatility.

Free float. We use free float as an inverse proxy for the presence of insiders since control blocks have generally superior access to private information (Leuz and Verrecchia, 2000). Hence, we expect a negative association between free float and share price volatility.

Analyst following. Prior studies (Atiase and Bamber, 1994; Imhoff and Lobo, 1992; Marquardt and Wiedman, 1998) argued that analyst following proxies for a firm's information that is publicly available. More specifically, Roulstone (2003) documents results that are consistent with analysts reducing information asymmetry by providing public information to market participants, while there is no support for analyst following functioning as a proxy for privately held information. A firm's analyst following is often used as a proxy for the level of other disclosures and the extent of a firm' communication with financial analysts (Leuz, 2003). Hence, we expect a negative relation between analyst following and share price volatility.

Environmental and social disclosures. To test our substitution hypothesis, we use two interaction terms: (1) Environmental disclosure in interaction with a binary variable, Social disclosure greater than the sample median, and (2) Social disclosure with a binary variable, Environmental disclosure greater than the sample median.

Three variables are introduced to capture the impact of corporate governance attributes as 
a monitoring factor: Board independence; Board size; and Audit committee.

Board independence. We expect board independence, measured as the proportion of outside directors, to be associated with share price volatility. Another aspect of board independence is the separation of the roles of Chair and Chief Executive Officer. Rechner and Dalton (1991) show that an independent leadership structure, in which two different persons are posted as Chair and CEO, monitors the top management effectively. Our variable takes the value of zero (0) when the majority of directors are not independent, one (1) when the majority of directors are independent and two (2) when the majority of directors are independent and the functions of CEO and Chair of the board are separate. We expect a negative relationship between this variable and share price volatility.

Board size. Some prior studies (e.g. Golden and Zajac, 2001; Vafeas, 1999) assume the relationship between board size and information asymmetry to be an inverted "U" shape, with an optimal board size existing midway. Below this optimal or the most efficient board size, there is a positive relation between board size and information asymmetry followed by a negative relationship. To account for the possible non-linear relationship between board size and information asymmetry, we will include board size as well as board size squared in our models. Hence, we expect board size to be negatively associated with share price volatility.

Audit committee size. In Canada, audit committees must comprise at least three independent members. We can argue that three is a small number for the audit committee to effectively play its monitoring role and that adding a few more members could be beneficial in that regard. Hence, we expect audit committee size to be negatively associated with share price volatility. 


\subsubsection{Determinants of Social and Environmental Disclosure}

Environmental performance. Many authors examine the association between environmental disclosure and a firm's environmental performance. Results are mixed. Ingram and Frasier (1980), Jaggi and Freedman (1982), Wiseman (1982), Rockness (1985), Freedman and Wasley (1990), and Fekrat, Inclan and Petroni (1996) do not find a significant association between environmental disclosure (in the annual report or in the 10K report) and the CEP index of environmental performance while Patten (2002a) establishes a negative relationship. Some recent works document a positive association between environmental performance and the extent of discretionary environmental disclosures (Clarkson, Li, Richardson and Vasvari, 2008; AlTuwaijri, Christensen and Hughes II, 2004). According to Al-Tuwaijri, Christensen and Hughes (2004), a positive relationship conjectures that prior literature's mixed results describing their interrelations may be attributable to the fact that researchers have not jointly considered Environmental disclosure, Environmental performance, and Economic performance. Legitimacy theory predicts a negative association between environmental performance and environmental disclosure. This relationship suggests that environmental disclosure is a function of social and political pressures facing firms (Aerts and Cormier, 2009). Environmental performance is computed by summing Canada's National Polluting Release Inventory (NPRI) of all facilities for an individual company in pounds deflated by $\$ 1,000$ of sales (Clarkson, Li, Richardson and Vasvari, 2008; Aerts and Cormier, 2009). To facilitate the interpretation of the results, we reverse the sign of this variable. In other words, the larger this measure is, the better the environmental performance. Consistent with prior studies on legitimacy theory (e.g. Patten, 2002a; Aerts and Cormier, 2009), we expect a negative relation between CSR disclosure and environmental performance. 
Free float. Ownership structure can determine the level of monitoring and, thereby, the extent of disclosure (Eng and Mak, 2003). Firms with widely held ownership are expected to be responsive to public investors' information costs since no dominant shareholders typically have access to the information they need (Hope, 2003; Roe, 2003). Therefore, a positive relation is expected between free float and disclosure.

Analyst following. Lang and Lundholm (1996) and Healy, Hutton and Palepu (1999) find a positive relation between analyst following and the quality of a firm's disclosure. Hence, we expect a positive relationship between analyst following and the extent of disclosure.

Leverage. Roberts (1992), Richardson and Welker (2001) and Elijido-Ten (2004) do not find any significant relationship between leverage and social disclosure while Clarkson, $\mathrm{Li}$, Richardson and Vasvari (2008) find a positive relationship between leverage and environmental disclosure based on Global Reporting Initiative Guidelines. Conversely, Cormier and Magnan (2003) document a negative relationship between leverage and environmental disclosure. ${ }^{2}$ Since the actual impact of leverage on environmental disclosure is unclear, no directional predictions are made for the variable.

Profitability. Many studies document a positive association between a firm's level of disclosure and its financial performance (Mills and Gardner, 1984; Cochran and Wood, 1984; McGuire, Sundgren and Schneeweis, 1988; Cormier and Magnan, 2003). Firms with superior earnings performance have a higher propensity to reveal their "good news". Hence, Murray, Sinclair, Power and Gray (2006) document that firms with consistently higher returns tend to

\footnotetext{
${ }^{2}$ An explanation for the inverse relationship (positive association for social disclosure and negative association for environmental disclosure) could be that social disclosure is more likely to be good news than environmental disclosure.
} 
have higher levels of total and voluntary social and environmental disclosure. In this vein, we expect a positive relationship between profitability and environmental disclosure.

Firm Size. Prior evidence is consistent in showing a positive relation between the extent of corporate disclosure and firm size (Scott, 1994; Neu, Warsame and Pedwell, 1998). Firm size also proxies other factors, such as the extent of monitoring by analysts. Firm size, measured as $\ln$ (Assets), is introduced with an expectation of a positive relation with disclosure.

Governance and media monitoring. Three variables are introduced to capture the impact of corporate governance as a monitoring factor affecting governance disclosure: Board independence; Board size; and Audit committee size. We expect a positive relationship between board effectiveness and disclosure. As for board size, to control for non-linearity in the relationship between board size and disclosure, we will include board size and board size squared in our models. Hence, we expect board size to be positively related to disclosure.

Environmental news exposure. A number of studies document that higher levels of media exposure relative to environmental issues increase public concerns and thus public policy pressure, to which companies react through greater environmental disclosure (Brown and Deegan, 1998; Deegan, Rankin and Voght, 2000; Patten, 2002b; Li, Richardson and Thornton, 1997; Bewley and Li, 2000). Hence, a positive relationship is expected between environmental media coverage and environmental disclosure as well as social disclosure.

\subsubsection{Variable measurement}

\section{Variable}

Systematic risk

Free float

Analyst following

Leverage

Profitability

\section{Measure}

Beta

The percentage of shares that are not closely held (total shares outstanding minus control blocks of $10 \%$ or more).

Number of analysts following a firm.

Long-term debt / Total assets

Return on assets 
Firm size

Board independence

Board size

Audit committee size

Environmental performance

Environmental news exposure
Ln(Total Assets) as of year-end

(0) if a majority of directors are not independent; (1) if a majority of directors are independent; (2) if a

majority of directors are independent and if the functions of CEO and Chair of the board are separated.

Number of directors on the board.

Number of audit committee members.

Toxic release inventory (TRI) of all facilities for an individual company in pounds deflated by $\$ 1,000$ of sales.

Articles related to environmental issues in 2004.

\section{Results}

\subsection{Descriptive statistics}

Table 1 provides some descriptive statistics about sample firms' financial and governance variables. Sample firms are relatively large (total assets averaging $\$ 5$ billion) and followed by seven analysts on average. About $78 \%$ of sample firms are free float. Systematic risk is close to the stock market risk, averaging 1.10, suggesting that our sample is a good representation of the Toronto Stock Exchange. Our sample firms have independent directors in a proportion of 36\%, with 20\% CEO and board chair duality.

\section{[Insert table 1]}

As illustrated in Table 2A, environmental disclosure score averages 27.76 (median of 10) while the social disclosure score shows a mean score of 18 (median of 11). Internal consistency estimates (Cronbach's alpha on score components) show that the variance is quite systematic (alpha varying from 0.77 to 0.82 for different components). This is slightly higher than Botosan (1997), who finds an alpha of 0.64 for an index including five categories of disclosure in annual reports. Cronbach's alpha estimates the proportion of variance in the test scores that can be 
attributed to true score variance. It can range from 0 (if no variance is consistent) to 1.00 (if all variances are consistent). According to Nunnaly (1978), a score of 0.70 is acceptable.

In table $2 \mathrm{~B}$, we observe that environmental management component shows the highest score (7.21) followed by Pollution abatement (6.88). Finally, among social disclosure components, the highest mean scores are observed for Society (9.89) and Labour practices and decent work (5.89).

[Insert table 2]

Table 3 presents correlations. Environmental disclosure (-0.13), Social disclosure (-0.21), Board size (-0.36), Profitability (-0.45) and Firm size (-0.46) are negatively and significantly correlated with Share price volatility. Environmental performance is correlated with Environmental disclosure (-0.33) and Social disclosure (-0.32), indicating that poor environmental performers are inclined to communicate more environmental information. This result is consistent with prior research arguing that environmental disclosure is a function of social and political pressures facing firms (Patten, 2002a). Environmental news exposure is positively associated with Environmental disclosure (0.39) and Social disclosure (0.38). Finally, Social disclosure is correlated with Environmental disclosure (0.54).

\section{[Insert table 3]}

\subsection{Multivariate Analyses}

First, we present results from an OLS regression on the determinants of environmental and social disclosures. We observe from table 4 that environmental performance, environmental news exposure and firm size are key drivers of disclosure. To a lesser extent, leverage and board size are related to environmental disclosure. 
[Insert table 4]

Since we posit that a firm's information dynamics affect environmental disclosure, social disclosure and share price volatility simultaneously, we first assess whether or not interaction exists between these variables using a Hausman test. Using this procedure, we reject the null hypothesis of no endogeneity with respect to Share price volatility and Environmental disclosure $(\mathrm{t}=3.49 ; \mathrm{p}<0.00)$ as well as Social disclosure $(\mathrm{t}=4.19 ; \mathrm{p}<0.00)$. Therefore, environmental disclosure variables are treated as endogeneous variables. In light of this diagnostic, we rely on a two-stage estimation procedure for a system of simultaneous equations. The software being used is STATA.

Table 5 reports results of a two-stage least square estimation. First, we discuss results for total disclosure. Consistent with the substitution hypothesis (H1a), the coefficient for the interaction term Social*Environmental median $(0.269 ; \mathrm{p}<0.05)$ is positive and significant, suggesting a substitution or compensating effect between social disclosure and environmental disclosure in reducing stock market asymmetry. Results show a negative and significant relationship between Share price volatility and the extent of social disclosure $(0.320 ; p<0.05)$. This result suggests that environmental disclosure and social disclosure might be part of an integrated reporting strategy by market participants. The compensating effect between environmental and social disclosures is particularly observed for hard environmental disclosure (economic-based) with the coefficient on Environmental $*$ Social median $(0.184 ; \mathrm{p}<0.10)$ also significant. Overall, CSR disclosure seems to reach a maximum in term of reducing share price volatility.

[Insert table 5] 
Economic-based environmental disclosure, so-called hard disclosure, is mainly comprised within the following four components of our content grid: expenditure and risk; compliance with laws and regulations; pollution abatement; and land remediation and contamination, whereas soft information relates to the 'sustainable development' and 'environmental management' grid captions. Disclosure about sustainable development and environmental management is likely to be more discretionary, less factual and objective, and easier to imitate even without substance to support the claims made. We estimate our model distinguishing between for hard and soft disclosures.

Results presented in table 5 also shows that only hard environmental disclosure is associated with a reduction in asymmetry between managers and investors $(-0.212 ; \mathrm{p}<0.10)$. This result is consistent with our hypothesis 2 , i.e. the reduction in share price volatility is higher for hard environmental disclosure than for soft environmental disclosure. Furthermore, this result is confirmed when combining in the same regression hard and soft environmental disclosure variables and computing a Student t-test for coefficient equality between environmental hard and environmental soft (coefficient for hard disclosure minus coefficient for soft disclosure $=0$ ). We observe an absence of equality between both coefficients $(\mathrm{t}=0.54 ; \mathrm{p}<0.463)$.

In addition, results suggest that for soft environmental disclosure, the substitution effect of environmental disclosure only operates for high environmental disclosure scores. We also observe that for high disclosing firms (both social and environmental), social disclosure has a larger impact in reducing share price volatility than environmental disclosure.

As a first sensitivity analysis, we estimate our model distinguishing between social component scores (Labour practices, Society, Consumer and product responsibility) and focusing 
on environmental hard disclosure. Results presented in table 6 show that disclosure about Society $(-0.270 ; p<0.018$ one-tailed $)$, and Labour practices $(-0.741 ; \mathrm{p}<0.026$ one-tailed $)$ are associated with a reduction in share price volatility while the substitution effect with hard environmental disclosure remains. As for Consumer and product responsibility disclosure, we observe a marginal impact on share price volatility $(-0.880 ; \mathrm{p}<0.125$ one-tailed $)$. The substitution effect of Customer and product responsibility disclosure with hard environmental disclosure is also marginal $(0.808 ; \mathrm{p}<0.254$ two-tailed). This result should be interpreted cautiously because the disclosure score of Consumer and product responsibility (2.22) is low compared with Society (9.89) and Labour (5.89). Hence, we think that it is appropriate to rely on total social disclosure in assessing the relationship between environmental disclosure and social disclosure.

[Insert table 6]

As a second sensitivity analysis, we replace share price volatility by share price. The model is the following: 


\section{Dependent variable}

Share price $_{\text {it }}=$

$f\left(b_{0}+b_{1}\right.$ Book value per share $+b_{2}$ Environmental disclosure $+b_{3}$ Environmental disclosure*Social median $+b_{4}$ Social disclosure $+b_{5}$ Social disclosure* Environmental median) it

Instrumented variable: Environmental disclosure, Social disclosure Instruments: Book value per share, Environmental performance, Free float, Analyst following, Leverage, Profitability, Firm Size, Board independence, Board size, Board size squared, Audit committee size, Environmental news exposure

Results shown in table 7 are in line with those presented in table 5. Consistent with the substitution hypothesis (H1a), the interaction term Social disclosure *Environmental median (2.192; $\mathrm{p}<0.05)$ is negative and significant, suggesting a substitution effect between social disclosure and environmental disclosure in stock price valuation. Again, the compensating effect is especially observed for hard environmental disclosure. Results also suggest that for soft environmental disclosure, the substitution effect only operates for high environmental disclosure scores. Results also show that only hard environmental disclosure is associated with stock price valuation. This result is consistent with our hypothesis 2 .

[Insert table 7]

\section{Conclusion}

Most prior research on corporate social responsibility (CSR) disclosure has considered environmental and social components as additive or complementary. In this paper, we explore 
the substitution or compensating effect between social disclosure and environmental disclosure in reducing information asymmetry between managers and investors.

Our results show that social disclosure and environmental disclosure substitute each other in reducing stock market asymmetry, especially for hard environmental disclosure.

Two approaches coexist in the measurement of CSR disclosure. On the one hand, starting with Wiseman (1982) and continuing with Cormier and Magnan (2003), Aerts and Cormier (2008) and Clarkson, Richardson and Vasvari (2008), disclosure is achieved by coding the nature of the information being provided. In other words, the information being disclosed is weighted according to its perceived relevance. On the other hand, there is a considerable body of research in which content is inferred by counting the number of words or sentences contained in annual or social responsibility reports (e.g., Neu et al., 1998; Richardson and Welker, 2001). Our results strongly indicate that investors assess the nature of the information being provided and distinguish more words from more substantive disclosures (e.g., hard disclosure vs. soft disclosure). In addition, future research in CSR disclosure may fruitfully distinguish between social and environmental disclosure as well as communication devices.

Regarding the determinants of environmental disclosure, our results show that environmental performance, environmental news exposure, leverage, and firm size are key drivers of CSR disclosure. More specifically, we find that a firm's environmental performance directly affects its CSR disclosure, with high polluting firms disclosing more than low polluting firms. This result is in stark contrast with the evidence by Clarkson, Richardson and Vasvari (2008) that poor (good) environmental performance translates into less (more) disclosure. Our finding corroborates prior research that relies on legitimacy theory (Cho and Patten, 2007; Aerts and Cormier, 2009). Hence, the issue is still unresolved and warrants further research. 
We also document that a firm's governance influences the extent of its CSR disclosure and, ultimately, affects information asymmetry between managers and investors. These findings are consistent with those reported by Bushman, Chen, Engel and Smith (2003) for the determination of financial reporting.

To the best of our knowledge, our study is the first to investigate the substitution effect of social disclosure for environmental disclosure, taking into account social disclosure, environmental performance and governance attributes.

The results of this study should be interpreted with caution at least for three reasons. First, our measure of social and environmental disclosures is based upon a coding instrument that makes some explicit assumptions about the value and relevance of information. However, such an approach is consistent with recent research efforts (e.g., Clarkson, Richardson and Vasvari, 2008). Second, sample size may be an issue. However, sample firms do represent a wide crosssection of Canada's industries as well as a significant proportion of the country's total stock market capitalization. 


\section{References}

Adler, P., Kwon, S.W., 2002. Social Capital: Prospects for a New Concept. Academy of Management Review 27 (1), 17-40

Aerts, W., Cormier, D., Magnan, M., 2007. The Association between Web-Based Corporate Performance Disclosure and Financial Analyst Behaviour under Different Governance Regimes. Corporate Governance - An International Review 15 (6), 1301-1328.

Aerts, W., Cormier, D., 2009. Media Legitimacy and Corporate Environmental Communication. Accounting, Organizations and Society 34 (1), 1-27.

Aerts, W., Cormier, D., Magnan, M., 2008. Corporate Environmental Disclosure, Financial Markets and the Media: An International Perspective. Ecological Economics 64, 643-659.

Al-Tuwaijri, S., Christensen, T.E., Hughes II, K.E., 2004. The Relations among Environmental Disclosure, Environmental Performance, and Economic Performance: A Simultaneous Equations Approach. Accounting, Organizations and Society 29, 447-471.

Ambec, S., Lanoie, P., 2008. Does It Pay to Be Green? A Systematic Overview. Academy of Management Perspectives 22, 45-62.

Atiase R., Bamber, L., 1994. Trading Volume Reactions to Annual Accounting Earnings Announcements: The Incremental Role of Predisclosure Information Asymmetry. Journal of Accounting and Economics (May), 309-329.

Barth, M.E., McNichols, M.F., 1994. Estimation and Market Valuation of Environmental Liabilities Relating to Superfund Sites. Journal of Accounting Research 32, supplement, 177-209. 
Bewley, K., Li, Y., 2000. Disclosure of Environmental Information by Canadian Manufacturing Companies: A Voluntary Disclosure Perspective, Advances in Environmental Accounting and Management 1, 201-226.

Botosan, C.A. (1997), Disclosure Level and the Cost of Equity Capital. The Accounting Review $72(3), 323-350$.

Botosan, C., Plumlee, M., 2005. Assessing Alternative Proxies for the Expected Risk Premium. The Accounting Review 80 (1), 21-53.

Brammer, S., Millington, A., 2008. Does it Pay to be Different? An Analysis of the Relationship between Corporate Social and Financial Performance. Strategic Management Journal 29, $1325-1343$.

Brown, N., Deegan, C., 1998. The Public Disclosure of Environmental Performance Information - A Dual Test of Media Agenda Setting Theory and Legitimacy Theory. Accounting and Business Research 29 (1), 21-41.

Bushman, R., Chen, Q., Engel, E., Smith, A., 2004. Financial Accounting Information, Organizational Complexity and Corporate Governance Systems. Journal of Accounting and Economics 37 (2), 167-201.

Burt R. S. (1992), Structural Holes: the Social Structure of Competition, Cambridge MA, Harvard UP.

Carroll, A.B., 1999. Corporate Social Responsibility - Evolution of a Definitional Construct. Business \& Society 38 (3), 268-295.

Chen, C.R., Steiner, T.L., 2000. Tobin's Q, Managerial Ownership, and Analyst Coverage: A nonlinear Simultaneous Equations Model. Journal of Economics and Business 52, 365-382. 
Chung, K.H., Jo, H., 1996. The Impact of Security Analysts’ Monitoring and Marketing Functions on the Market Value of Firms. Journal of Financial and Quantitative analysis 31 (4), 493-512.

Cho, C.H., Patten, D.M., 2007. The Role of Environmental Disclosures as Tools of Legitimacy: A Research Note. Accounting, Organizations and Society 32 (7/8), 639-647.

Clarkson, P., Li, Y., Richardson, G.D., Vasvari, F.P., 2008. Revisiting the Relation between Environmental Performance and Environmental Disclosure: An Empirical Analysis. Accounting, Organizations and Society 33, 303-327.

Cochran, P., Wood, R., 1984. Corporate Social Responsibility and Financial Performance. Academy of Management Journal, 42-56.

Collett, P., Hrasky, S., 2005. Voluntary Disclosure of Corporate Governance Practices by Listed Australian Companies. Corporate Governance: An International Review 13 (2), 188-196.

Cormier, D., Aerts, W., Ledoux M.J., Magnan, M., 2009. Attributes of Social and Human Capital Disclosure and Information Asymmetry between Managers and Investors. Canadian Journal of Administrative Sciences 26 (1), 71-88.

Cormier, D., Ledoux, M.J., Magnan, M., 2009. The Use of Web Sites as a Disclosure Platform for Corporate Performance. International Journal of Accounting Information Systems 10 (1), $1-24$

Cormier, D., Magnan, M., 2003. Environmental Reporting Management: A European Perspective. Journal of Accounting and Public Policy 22, 43-62.

Cormier, D., Magnan, M., 2006. The Revisited Contribution of Environmental Reporting to Investors' Valuation of a Firm's Earnings: An International Perspective. Ecological Economics 63 (3-4), 613-626. 
Deegan, C., Rankin, M., Voght, P., 2000. Firms' Disclosure Reactions to Major Social Incidents: Australian Evidence. Accounting Forum 24 (1), 101-130.

Dess, G.G., Shaw, J.D., 2001. Voluntary Turnover, Social Capital, and Organizational Performance. Academy of Management Review 26 (3), 446-456.

Downing, P., 1997. Upping the Stakes. CaMagazine June, 41-43.

Elijido-Ten, E., 2004. Determinants of Environmental Disclosures in a Developing Country: An Application of the Stakeholder Theory. Fourth Asia Pacific Interdisciplinary Research in Accounting Conference, Singapore.

Eng L.L., Mak, Y T., 2003. Corporate Governance and Voluntary Disclosure. Journal of Accounting and Public Policy 22, 325-345.

Feier, H., Haskell, V., 2008. Corporate Social Responsibility Turns Green. Environmental Outlook, www.djc.com.

Fekrat, M.A., Inclan, C., Petroni, D., 1996. Corporate Environmental Disclosures: Competitive Disclosure Hypothesis Using 1991 Annual Report Data. The International Journal of Accounting 31 (2), 175-195.

Fombrun, C., Shanley, M., 1990. What's in a Name? Reputation Building and Corporate Strategy. Academy of Management Journal 33, 233-258.

Freedman, M., Wasley, C., 1990. The Association between Environmental Performance and Environmental Disclosure in Annual Reports and 10Ks, Advances in Public Interest Accounting, 183-193.

Francis, J., Khurana, I., Pereira, R., 2005. Disclosure Incentives and Effects on Cost of Capital. The Accounting Review 80 (4), 1125-1162. 
Gebhardt, W., Lee, C., Swaminathan, B., 2001. Toward an Implied Cost of Capital. Journal of Accounting Research 39 (1), 135-176.

Gelb, D.S., Strawser, J.A., 2001. Corporate Social Responsibility and Financial Disclosures: An Alternative Explanation for Increased Disclosure. Journal of Business Ethics 33, 1-13.

Godfrey, P.C., Merrill, C.B., Hansen, J.M., 2009. The Relationship between Corporate Social Responsibility and Shareholder: An Empirical Test of the Risk Management Hypothesis. Strategic Management Journal 30, 425-445.

Golden, B. R., Zajac, E. J., 2001. When Will Boards Influence Strategy? Inclination $\times$ Power $=$ Strategic Change. Strategic Management Journal 22, 1087-1117.

Gray, R., Bebbington, J., 2007. Corporate Sustainability, Accountability and the Pursuit of the Impossible Dream. In Handbook of Sustainable Development; Atkinson G. S., S. Dietz, E. Neumeyer (ed); Edward Elgar, Cheltenham, UK.

Griffin, J.J., Mahon, J.F., 1997. The Corporate Social Performance and Corporate Financial Performance Debate: Twenty-five years of Incomparable Research. Business \& Society 36, $5-31$.

Hail, L., Leuz, C., 2006. International Differences in the Cost of Equity Capital: Do Legal Institutions and Securities Regulation Matter. Journal of Accounting Research 44 (3), 485531.

Healy, P., Hutton, A.P., Palepu, K.G., 1999. Stock Performance and Intermediation Changes Surrounding Sustained Increases in Disclosure. Contemporary Accounting Research 16 (3), 485-520.

Hill, C.W.L., 1990. Cooperation, Opportunism, and the Invisible Hand: Implications for Transaction Cost Theory. Academy of Management Review 15, 500-513. 
Hitt, M.A., Lee, H.U., Yucel, E., 2002. The Importance of Social Capital to the Management of Multinational Enterprises: Relational Networks among Asian and Western Firms. Asia Pacific Journal of Management 19, 353-372.

Hope, O.K., 2003. Disclosure Practices, Enforcement of Accounting Standards and Analysts' Forecasts Accuracy: An International Study. Journal of Accounting Research 41 (2), 273272.

Imhoff, E. A. Jr., Lobo, G. J., 1992. The Effect of Ex Ante Earnings Uncertainty on Earnings Response Coefficients. The Accounting Review 67 (2), 427-439.

Industry Canada, 2006. Corporate Social Responsibility: An Implementation Guide for Canadian Business. Government of Canada, Ottawa.

Ingram R.W., 1978. An Investigation of the Information Content of (Certain) Social Responsibility Disclosure. Journal of Accounting Research 16 (2), 270-285.

Ingram, R.W., Frazier, K.B., 1980. Environmental Performance and Corporate Disclosure. Journal of Accounting Research 18, Autumn, 615-22.

Jackson, G., Apostolakou, A. 2009. Corporate Social Responsibility in Western Europe: An Institutional Mirror or Substitute. Journal of Business Ethics. Published online.

Jaggi, B., Freedman, M., 1982. An Analysis of the Informational Content of Pollution Disclosures. The Financial Review, 142-152.

Lang, M., Lundholm, R. 1996. Corporate Disclosure Policy and Analyst Behavior. The Accounting Review 71 (2), 467-492.

Lang, L., Stulz, R., 1994. Tobin's Q, Corporate Diversification, and Firm Performance. Journal of Political Economy 102 (6), 1248-1280.

Lenzen, M., Dey, C.J. and Murray, S.A. 2004. Historical accountability and cumulative impacts: 
the treatment of time in corporate sustainability reporting. Ecological Economics 51, 237250.

Leuz, C., 2003. IAS Versus US-GAAP: Information Asymmetry-Based Evidence from Germany’s New Market. Journal of Accounting Research 41 (3), 445-472.

Leuz, C., Verrecchia, R., 2000. The Economic Consequences of Increased Disclosure. Journal of Accounting Research 38 (supplement), 91-124.

Li, Y., McConomy, B.J., 1999. An Empirical Examination of Factors Affecting the Timing of Environmental Accounting Standard Adoption and the Impact on Corporate Valuation. Journal of Accounting, Auditing \& Finance 14 (3), 279-313.

Li, Y., Richardson, G. D., Thornton, D.B., 1997. Corporate Disclosure of Environmental Liability Information: Theory and Evidence. Contemporary Accounting Research 14 (3), 435-474.

Margolis, J.D., Walsh, J.P., 2003. Misery Loves Companies: Rethinking Social Initiatives by Business. Administrative Science Quarterly 48, 655-689.

Marquardt, C. A., Wiedman, C. I., 1998. Voluntary Disclosure, Information Asymmetry, and Insider Selling Through Secondary Equity Offerings. Contemporary Accounting Research 15(4), 505-537.

McGuire, J., Sundgren, A., Schneeweis, T., 1988. Corporate Social Responsibility and Firm Financial Performance. Academy of Management Journal, December, 854-872.

McWilliams, A., Siegal, P.M., Wright, D., 2006. Guest Editors' Introduction, Corporate Social Responsibility: Strategic Implications. Journal of Management Studies 43, 1-18. 
Marston, C.L., Polei, A., 2004. Corporate Reporting on the Internet by German Companies. International Journal of Accounting Information Systems 5 (3), 285-311.

Mikhail, M., Walther, B., Willis, R., 2004. Earnings Surprises and the Cost of Equity Capital. Journal of Accounting, Auditing and Finance 19 (4), 491-513.

Milgrom, P., Roberts, J., 1992. Economics, Organizations, and Management. Englewood Cliffs, NJ, Prentice Hall.

Mills, D., Gardner, M., 1984. Financial Profiles and the Disclosure of Expenditures for Socially Responsible Purposes. Journal of Business Research, December, 407-424.

Murray, A., Sinclair, D., Power, D., Gray, R., 2006. Do Financial Markets Care about Social and Environmental Disclosure? Accounting, Auditing and Accountability Journal 19 (2), 228255.

Neu, D., Warsame, H., Pedwell, K., 1998. Managing Public Impressions: Environmental Disclosures in Annual Reports. Accounting, Organizations and Society 23(3), 265-282. Nunnaly, J. (1978), Psychometric Theory. McGraw Hill, 2nd Edition, New York.

Orlitzky, M., Benjamin, J.D., 2001. Corporate Social Performance and Firm Risk: A MetaAnalytical Review. Business \& Society 40(4), 369-396.

Orlitzky, M., Schmidt, F.L., Rynes, S.L., 2003. Corporate Social and Financial Performance: A meta-analysis. Organization Studies 24, 403-441.

Patten, D.M., 1991. Exposure, Legitimacy, and Social Disclosure. Journal of Accounting and Public Policy 10, 297-308.

Patten, D.M., 2002a. The Relation between Environmental Performance and Environmental Disclosure: A Research Note. Accounting. Organizations and Society 27, 763-773. 
Patten, D.M., 2002b. Media Exposure, Public Policy Pressure, and Environmental Disclosure: An Examination of the Impact of Tri Data Availability. Accounting Forum 26 (2), 153-171. Pastoriza, D., Arino, M.A., Ricart, J.E., 2008. Ethical Managerial Behaviour as an Antecedent of Organizational Social Capital. Journal of Business Ethics 78, 329-341.

Pava, M.L., Krausz, J., 1996. The Association between Corporate Social-Responsibility and Financial Performance: The Paradox of Social Costs. Journal of Business Ethics 15, 321357.

Pirchegger, B., Wagenhofer, A., 1999. Financial Information on the Internet: A Survey of Homepages of Austrian Companies. The European Accounting Review 8 (2), 383-395. Richardson, A., Welker, M., 2001. Social Disclosure, Financial Disclosure and the Cost of Equity Capital. Accounting, Organizations and Society 26 (7), 597-616.

Rechner, P.L., Dalton, D.R., 1991. CEO Duality and Organizational Performance: A Longitudinal. Analysis, Strategic Management Journal 12, 155-160.

Roberts, C. B., 1992. Determinants of Corporate Social Responsibility Disclosure: An Application of Stakeholder Theory. Accounting, Organizations and Society 17 (6), 595-612. Rockness, J.W., 1985. An Assessment of the Relationship Between US Corporate Environmental Performance and Disclosure. Journal of Business Finance \& Accounting 12 (3), 339-354.

Roe, M. J., 2003. Political Determinants of Corporate Governance. Oxford University Press: New York.

Roman, R.M., Hayibor, S., Alge, B.R., 1999. The Relationship between Social and Financial Performance: Repainting a Portrait. Business \& Society 38, 109-125.

Roulstone, D.T., 2003. The Relation between Insider-Trading Restrictions and Executive Compensation. Journal of Accounting Research 41, 525-551. 
Scott, T., 1994. Incentives and Disincentives for Financial Disclosure: Voluntary Disclosure of Defined Benefit Pension Plan Information by French Firms. The Accounting Review 69 (1), 26-43.

Shane, S., Cable, D., 2002. Networks Ties Reputation and the Financing of New Ventures. Management Science 48 (3), 364-381.

Vafeas, N., 1999. Board Meeting Frequency and Firm Performance. Journal of Financial Economics 53, 113-142.

Waddock, S.A., Graves, S.B., 1997. The Corporate Social Performance-Financial Performance Link. Strategic Management Journal 18, 303-319.

Welker, M., 1995. Disclosure Policy, Information Asymmetry and Liquidity in Equity Markets. Contemporary Accounting Research 11 (3), 801-828.

Williams, S.M., Ho Wern Pei, C.A., 1999. Corporate Social Disclosures by Listed Companies on their Web sites: An International Comparison. The International Journal of Accounting 34 (3), 389-419.

Wiseman, J., 1982. An Evaluation of Environmental Disclosures Made in Corporate Annual Reports. Accounting, Organizations and Society 7 (4), 53-64.

Wood, D.J., Jones, R.E., 1995. Stakeholder Mismatching: A Theoretical Problem in Empirical Research on Corporate Social Performance. International Journal of Organizational Analysis 3, 229-267.

Ziegler, A., Schroder, M. 2009. What determines the inclusion in a sustainability stock index? A panel data analysis for European firms. Ecological Economics. Published online. 
Table 1

Descriptive statistics

Financial and governance variables

\begin{tabular}{lrrrr}
\hline N: 137 & Min. & Max. & Mean & $\begin{array}{r}\text { Standard } \\
\text { deviation }\end{array}$ \\
\hline Share price volatility & & & & 1.228 \\
Systematic risk & 0.818 & 8.828 & 1.135 & 0.577 \\
Free float & -0.200 & 2.800 & 0.777 & 0.225 \\
Analyst following & 0.098 & 1.000 & 7 & 5.892 \\
Board independence & 0 & 35 & 0.919 & 0.513 \\
Independent directors & 0 & 2 & 0.360 & 0.178 \\
Board chair duality & 0 & 0.860 & 0.200 & 0.401 \\
Board size & 0 & 1 & 10 & 2.718 \\
Audit committee size & 4 & 9 & 4 & 1.106 \\
Leverage & 3 & 0.99 & 0.232 & 0.203 \\
Profitability & 0 & 0.387 & 0.025 & 0.139 \\
Firm size (in millions of \$) & -1.151 & 39000 & 5057 & 7389 \\
\hline
\end{tabular}


Table 2A

Descriptive statistics

Environmental and social disclosures

\begin{tabular}{lrrrrrr}
\hline N: 137 & Min. & Max. & Mean & Median & $\begin{array}{c}\text { Standard } \\
\text { Deviation }\end{array}$ & $\begin{array}{r}\text { Cronbach } \\
\text { Alpha }\end{array}$ \\
\hline $\begin{array}{l}\text { Environmental news } \\
\text { exposure }\end{array}$ & 0 & 6 & 0.366 & 0 & 0.944 & -- \\
Environmental performance & 0 & 25.78 & 0.735 & 0 & 2.530 & -- \\
\hline Environmental disclosure & 0 & 134 & 27.765 & 10 & 35.608 & 0.82 \\
\hline Social disclosure & 0 & 97 & 18.003 & 11 & 18.000 & 0.77 \\
\hline
\end{tabular}


Table 2B

Descriptive statistics

Environmental and social disclosures by components

\begin{tabular}{lrr}
\hline N: 137 & Environmental & Social \\
\hline & Mean & Mean \\
\hline Expenditures and risks & 2.919 & \\
Laws and regulations conformity & 1.899 & 6.879 \\
Pollution abatement & 4.006 & 5.892 \\
Sustainable development & 4.852 & 9.891 \\
Land remediation and contamination & 7.208 & 2.216 \\
Environmental management & & 18.003 \\
& & \\
Labour practices and decent work & & \\
Society & & \\
Consumer and product responsibility & & \\
\hline Total & & 27.765 \\
\hline
\end{tabular}


Table 3

Correlation matrix

\begin{tabular}{|c|c|c|c|c|c|c|c|c|c|c|c|c|c|c|c|}
\hline & & 1 & 2 & 3 & 4 & 5 & 6 & 7 & 8 & 9 & 10 & 11 & 12 & 13 & 14 \\
\hline 1 & Share price volatility & 1 & $* 0.29$ & 0.03 & -0.08 & $*_{-} 0.13$ & $*_{-} 0.21$ & -0.02 & $*-0.36$ & -0.31 & -0.01 & -0.07 & $*_{-}-0.45$ & $*_{-}-0.46$ & -0.10 \\
\hline 2 & Systematic risk & & 1 & $* 0.19$ & $* 0.24$ & 0.08 & $* 0.15$ & 0.05 & -0.03 & -0.01 & -0.05 & $*_{-}-0.14$ & 0.10 & $* 0.13$ & -0.01 \\
\hline 3 & Free float & & & 1 & $* 0.12$ & 0.04 & 0.05 & 0.14 & -0.08 & 0.05 & 0.01 & $*_{-}-0.30$ & -0.03 & -0.06 & 0.01 \\
\hline 4 & Analyst following & & & & 1 & 0.02 & $* 0.18$ & -0.12 & 0.02 & 0.04 & -0.02 & $*_{-}-0.29$ & 0.10 & $* 0.14$ & $* 0.13$ \\
\hline 5 & Environmental disclosure & & & & & 1 & $* 0.54$ & -0.01 & $* 0.22$ & $* 0.20$ & $*_{-0.33}$ & 0.02 & $* 0.15$ & $* 0.49$ & $* 0.39$ \\
\hline 6 & Social disclosure & & & & & & 1 & -0.02 & $* 0.30$ & $* 0.33$ & $*_{-0.32}$ & 0.03 & $* 0.17$ & $* 0.54$ & $* 0.38$ \\
\hline 7 & Board independence & & & & & & & 1 & 0.09 & 0.07 & -0.02 & $*_{-}-0.14$ & -0.10 & -0.07 & -0.08 \\
\hline 8 & Board size & & & & & & & & 1 & $* 0.55$ & $*_{-0.13}$ & $* 0.17$ & $* 0.16$ & $* 0.54$ & 0.08 \\
\hline 9 & Audit committee size & & & & & & & & & 1 & $*_{-0.18}$ & 0.11 & $* 0.19$ & $* 0.38$ & 0.07 \\
\hline 10 & Environmental performance & & & & & & & & & & 1 & 0.07 & -0.07 & $*_{-} 0.22$ & -0.09 \\
\hline 11 & Leverage & & & & & & & & & & & 1 & 0.07 & $* 0.29$ & 0.01 \\
\hline 12 & Profitability & & & & & & & & & & & & 1 & $* 0.29$ & 0.07 \\
\hline 13 & Firm size & & & & & & & & & & & & & 1 & $* 0.23$ \\
\hline 14 & $\begin{array}{l}\text { Environmental news } \\
\text { exposure }\end{array}$ & & & & & & & & & & & & & & 1 \\
\hline
\end{tabular}


Table 4

OLS Estimation of the Determinants of

Environmental and social Disclosure

\begin{tabular}{|c|c|c|c|}
\hline & $\begin{array}{l}\text { Predicted } \\
\text { sign }\end{array}$ & Environmental disclosure & Social disclosure \\
\hline Environmental performance & - & $* * *-2.478$ & $* * *-1.266$ \\
\hline \multicolumn{4}{|l|}{ Information costs and benefits } \\
\hline Free float & + & 6.739 & $* 5.601$ \\
\hline Analyst following & $?$ & $* * *-0.996$ & 0.191 \\
\hline Leverage & $?$ & $*-24.812$ & -7.350 \\
\hline Profitability & + & -4.576 & -5.926 \\
\hline Firm size & + & $* * * 10.301$ & $* * * 4.553$ \\
\hline \multicolumn{4}{|c|}{ Governance and media monitoring } \\
\hline Board independence & + & 0.607 & 0.659 \\
\hline Board size & + & $* * * 14.906$ & $* * 4.163$ \\
\hline Board size squared & - & $* * *-0.748$ & $* *_{-} 0.197$ \\
\hline Audit committee size & + & 2.289 & $* * 2.611$ \\
\hline Environmental news exposure & + & $* * * 10.479$ & $* * * 4.711$ \\
\hline Adjusted $\mathrm{R}^{2}$ & & $42.46 \%$ & $43.107 \%$ \\
\hline F statistic ( $\mathrm{P}$ value) & & $9.18(0.000)$ & $13.1(0.00)$ \\
\hline
\end{tabular}

$*: \mathrm{p}<0.10 ; * *: \mathrm{p}<0.05 ; * * *: \mathrm{p}<0.01$. One-tailed if there is a predicted sign, two-tailed otherwise. 
Table 5

2SLS Estimation of the Relationship between

Environmental and Social Disclosures and Share Price Volatility

\begin{tabular}{|c|c|c|c|c|}
\hline & & \multicolumn{3}{|c|}{ Share price volatility } \\
\hline & & $\begin{array}{r}\text { Environmental } \\
\text { Total }\end{array}$ & $\begin{array}{r}\text { Environmental } \\
\text { Hard }\end{array}$ & $\begin{array}{r}\text { Environmental } \\
\text { Soft }\end{array}$ \\
\hline \multicolumn{5}{|l|}{ Share price volatility } \\
\hline Systematic risk & + & $* * 0.906$ & $* 0.553$ & $* * * 0.902$ \\
\hline Free float & - & 0.666 & 1.058 & 0.400 \\
\hline Analyst following & - & -0.012 & -0.018 & -0.023 \\
\hline Environmental & - & -0.123 & $*_{-} 0.212$ & -0.115 \\
\hline Environmental*Social median & $?$ & 0.103 & $* 0.184$ & 0.085 \\
\hline Social & - & $*_{-} *_{-0.320}$ & $* * *_{-} 0.291$ & $* * *-0.217$ \\
\hline Social*Environmental median & $?$ & $* * 0.269$ & $* * 0.236$ & $* * * 0.183$ \\
\hline Adjusted $\mathrm{R}^{2}$ & & $41.05 \%$ & $42.05 \%$ & $40.16 \%$ \\
\hline $\mathrm{F}$ (P value $)$ & & $6.46(0.00)$ & $6.52(0.00)$ & $6.30(0.00)$ \\
\hline
\end{tabular}

$*: \mathrm{p}<0.10 ; * *: \mathrm{p}<0.05 ; * * *: \mathrm{p}<0.01$.One-tailed if there is a predicted sign, two-tailed otherwise.

Instrumented variable: Environmental disclosure, Social disclosure

Instruments: Environmental performance, Free float, Analyst following, Leverage, Profitability, Firm Size, Board independence, Board size, Board size squared, Audit committee size, Environmental news exposure 
Table 6

2SLS Estimation of the Relationship between

Hard Environmental disclosure, Social Disclosures and Share Price Volatility

\begin{tabular}{|c|c|c|c|c|}
\hline & \multicolumn{4}{|c|}{ Share price volatility } \\
\hline & & Labour & Society & $\begin{array}{r}\text { Consumer and } \\
\text { product }\end{array}$ \\
\hline \multicolumn{5}{|l|}{ Share price volatility } \\
\hline Systematic risk & + & $* * 0.775$ & $* * 0.578$ & $* * * 0.909$ \\
\hline Free float & - & 0.778 & 0.362 & 0.806 \\
\hline Analyst following & - & -0.010 & -0.018 & $* *-0.060$ \\
\hline Environmental & - & $* *_{-} 0.145$ & $* *_{-} 0.127$ & $* *-0.065$ \\
\hline Environmental*Social median & $?$ & *0.119 & $* * 0.106$ & $* * 0.049$ \\
\hline Social & - & $* *-0.741$ & $* *-0.271$ & -0.880 \\
\hline Social*Environmental median & $?$ & $* * 0.639$ & $* * 0.215$ & 0.808 \\
\hline Adjusted $\mathrm{R}^{2}$ & & $36.70 \%$ & $41.03 \%$ & $35.24 \%$ \\
\hline $\mathrm{F}(\mathrm{P}$ value $)$ & & $4.05(0.00)$ & $6.28(0.00)$ & $6.46(0.00)$ \\
\hline
\end{tabular}

$*: \mathrm{p}<0.10 ; * *: \mathrm{p}<0.05 ; * * *: \mathrm{p}<0.01$. One-tailed if there is a predicted sign, two-tailed otherwise.

Instrumented variable: Environmental disclosure, Social disclosure

Instruments: Environmental performance, Free float, Analyst following, Leverage, Profitability, Firm Size, Board independence, Board size, Board size squared, Audit committee size, Environmental news exposure. 
Table 7

2SLS Estimation of the Relationship between Environmental and Social Disclosures and Share Price

\begin{tabular}{|c|c|c|c|c|}
\hline & \multicolumn{4}{|c|}{ Share Price } \\
\hline & & $\begin{array}{r}\text { Environmental } \\
\text { Total }\end{array}$ & $\begin{array}{r}\text { Environmental } \\
\text { Hard }\end{array}$ & $\begin{array}{r}\text { Environmental } \\
\text { Soft }\end{array}$ \\
\hline Book value per share & + & $* * * 1.061$ & $* * 0.911$ & $* * * 1.107$ \\
\hline Environmental & + & 1.253 & $* 2.441$ & 1.613 \\
\hline Environmental*Social median & $?$ & -1.089 & $*-2.068$ & -1.432 \\
\hline Social & + & $* * 2.192$ & $* * 2.574$ & $* * 1.723$ \\
\hline Social*Environmental median & $?$ & $*_{-1.943}$ & $* *-2.319$ & $*_{-1} 1.537$ \\
\hline Adjusted $\mathrm{R}^{2}$ & & $45.32 \%$ & $38.51 \%$ & $45.01 \%$ \\
\hline Chi2 (P value) & & $7.27(0.00)$ & $7.36(0.00)$ & $8.66(0.00)$ \\
\hline
\end{tabular}

$*: \mathrm{p}<0.10 ; * *: \mathrm{p}<0.05 ; * * *: \mathrm{p}<0.01$. One-tailed if there is a predicted sign, two-tailed otherwise.

Instrumented variable: Environmental disclosure, Social disclosure

Instruments: Book value per share, Environmental performance, Free float, Analyst following, Leverage, Profitability, Firm Size, Board independence, Board size, Board size squared, Audit committee size, Environmental news exposure 


\section{Appendix 1}

\section{Environmental disclosure grid}

\begin{tabular}{ll}
\hline Expenditures and risks & Sustainable development \\
Investments & Natural resource conservation \\
Operation costs & Recycling \\
Future investments & Life cycle information \\
Future operating costs & Land remediation and contamination \\
Financing for investments & Sites \\
Environmental debts & Efforts of remediation \\
Risk provisions & Potential liability- remediation \\
Risk litigation & Implicit liability \\
Provision for future expenditures & Spills (number, nature, efforts of reduction) \\
Laws and regulations & Environmental management
\end{tabular}

conformity

Litigation, actual and potential

Environmental policies or company concern for the environment

Fines

Orders to conform

Corrective action

Incidents

Future legislation and regulations

Pollution abatement

Emission of pollutants

Discharges

Waste management

Installation and process controls

Environmental management system

Environmental auditing

Goals and targets

Awards

Department, group, service affected to the environment

ISO 14000

Involvement of the firm in the development of environmental standards Involvement in environmental organizations (industry committees, etc)

Compliance status of facilities

Joint projects with other firms providing environmental management services

Noise and odours

Rating scale:

3: Item described in monetary or quantitative terms; 2 : Item described specifically; 1 : Item discussed in general

\section{Social disclosure grid}

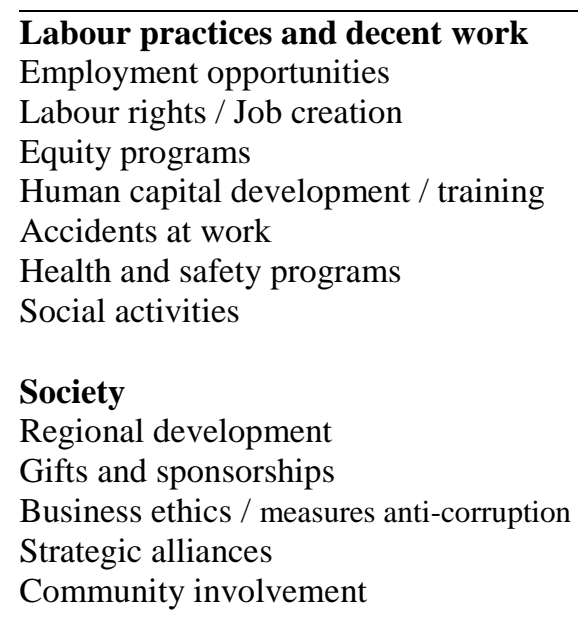

\section{Consumer and product responsibility}

Purchases of goods and services

Product-related incidents

Product development and environment

Consumer heath and safety /Product safety

Rating scale:

3: Item described in monetary or quantitative terms; 2: Item described specifically; 1: Item discussed in general 


\section{Appendix 2}

\section{News media content}

News media content is extracted from the ABI/Inform Global database and from three distinct sources:

(1) Business, Economics: local and regional business publications (local and regional business news coverage of large corporations, privately held companies, local start-ups, executive profiles, marketing, finance, and industry news. ABI Inform provides access to business information not typically found in national news sources. It contains news and analysis, information on local markets, and more data gathered from major business tabloids, magazines, daily newspapers, wire services, and city, state, and regional business publications;

(2) Business, Finance, Economics: journals, company profiles, Wall Street Journal (most scholarly and comprehensive way to explore and understand business research topics. It includes nearly 1,800 worldwide business periodicals for in-depth coverage of business and economic conditions, management techniques, theory, and business practices, advertising, marketing, economics, human resources, finance, taxation, computers, and more. It constitutes extensive international coverage with quick access to information on more than 60,000 companies with business and executive profiles);

(3) Canadian Newsstand, which offers unparalleled access to the full text of Canadian newspapers (Montreal Gazette, National Post and Toronto Star). We extracted articles using a firm's name and the following keywords: "environment", "sustainable development", "recycling", "pollution", "toxic", "ISO14000", “conservation", "remediation", "spills", "waste management”, “energy", "awards", "environmental audit". 